\title{
Preface: And property for all?
}

Sectarianism, fed by fanaticism, is always castrating. Radicalism, nourished by a critical spirit, is always creative ... sectarianism, because it is mythicized and irrational, turns reality into a false (and therefore unchangeable) 'reality'. ${ }^{1}$

In Pedagogy of the Oppressed ${ }^{2}$ Paulo Freire identified the contradiction between the oppressor and the oppressed and how it might be overcome.

The oppressed suffer from the duality which has established itself in their innermost being. They discover that without freedom they cannot exist authentically. Yet although they desire authentic existence they fear it. They are one at the same time themselves and the oppressor whose consciousness they have internalised. ${ }^{3}$

Property, as it is currently commodified in disembedded exchange markets, is oppressive. Those who can't afford access to property and who accept the exclusive barriers of rights and scarcity suspend a disbelief in market inequalities, and lose a social imagination that freer access is possible. Liberation through a counter-narrative about property and a collective conscience that resists alienation and asymmetry is not a gift to the oppressed (from law or processes of formal entitlement). Equitable property enjoyment unburdened of inflated rent cannot be realised through self-achievement alone. The emancipation of property for the presently disenfranchised requires a mutual process that, we will argue, demands new arrangements between law, property and the social.

Law's regulatory relevance is tested by contemporary revolutions in access to property. Fundamental rifts in the power asymmetries that have characterised neo-liberal exchange markets are emerging more starkly as a result of mass radical repositioning in collective consciences concerning property, its value and its social location. In its commodified form law is a force for disembedding property markets from the social and generating fictitious value through the creation and maintenance of

1 Freire, P. (2015), Pedagogy of the Oppressed, London: Bloomsbury, p. 37.

Freire (2015).

3 Freire (2015), p. 48. 
artificial scarcity. This book explores how grassroots resistance to exclusionist property regimes are challenging law to return to a role as a communal resource. If this is achieved, we argue that law will vitally influence how more socially-located property can be imagined, appropriated, objectified, incorporated and converted by communities of users which up until now were largely factored out of the market as a consequence of fictitious commodification.

Capitalism is a story of property. Law's role in the advance of capitalism has been to order the tools required by commodity pricing that ensure abundance for the propertied and alienation for the disempowered. The unravelling of capitalist exchange markets and the inexorable end to global economic growth present vibrant possibilities for what we call new law, original property and communal resilience. At first, our project was to employ a Polanyian analysis to reveal the marginalisation of law in periods of market change, and craft an argument for law's relevance as a force in the second phase of Polanyi's double movement, addressing the inevitable strains caused by this transition. The revisionist tone inherent in such an exercise demanded a rethink. What follows is a much more expansive and adventurous case for law's regulatory relevance, with law transformed into a communal resource, markets returned to the social, and property again representing relationships of trust. The theorising is inclusive of Polanyi, Durkheim, Proudhon and Cotterrell. The methodology employs the predispositions of these theorists and adds a new appreciation of the embedding dynamic assisted through the application of suspension as a novel analytical device. The theoretical challenge looks at dismantling property and commodity pricing, the union of which law has solemnised in its neoliberal abdication of communal normative foundations. Our faith in law's regulatory relevance is founded in the return of exchange markets to the community, but with law as an essential piece of the deal. The fallacy of materialist abundance for the many, in favour of excess for the few offers the fuel for inverting capitalist priorities and replacing these with communitarian inevitabilities.

Kelly predicts the magnitude of an emerging post-capitalist epoch:

We are now engaged in a grand scheme to augment, enhance and extend the relationships and communications between all beings and all objects. ${ }^{4}$

The neo-liberal economic model promised abundance for all. It is true the proportion of the world's population that is starving has been reduced

4 Kelly, K. (1997), 'New rules for the new economy', as quoted in Mason, P. (2015a), Postcapitalism, London: Allen and Lane, p. 107. 
through economic development and in countries such as China a middle class has been born in recent decades. However, what abundance is claimed has come at a terrible price. Global warming and the destruction of natural resources means that the future is bleak. Economic growth in the major North World markets has stalled. The wealth gap has exploded so that any promise of a more equitable distribution of abundance is as illusory as any sustainable abundance itself.

After years of neo-liberal indoctrination and legal agency property exclusion, society intuitively ties the value of property to the cash it commands. Polanyi's fictitious commodities are no longer confined to land, labour and money but involve a vast range of space and social interconnections which represent property in our present age. Commodified law intones what can be priced, can be owned. Legal agency upholds the ineffable bond between property and price. Attempts at severing this neo-liberal cord, law deems as theft. The resistant communities that seize access to otherwise-alienated property laugh at law and skirt its boundaries to achieve their enjoyment.

Our vision of this grand scheme of communication and relationship is a transition from exclusionist economies to accessible communities. Essential in this transition will be the reconceptualisation of property from that now secured by the law. Law's function in the commodification of property and therefrom, the development of commodity economies, ${ }^{5}$ has been to ensure the alienation and transaction of property, the rights of the propertied and property's exchange value. However, by lending itself to the neo-liberals in this process, law's integrity too has been commodified within markets that are disembedded from the social. ${ }^{6}$

As an ally of neo-liberalism, law has succeeded in its creation of sectoral abundance as well as the stark market asymmetries on which burgeoning wealth gaps depend. As a regulatory force for general social good, law in its neo-liberal mode has failed, ${ }^{7}$ requiring us to return to the

5 For a discussion of commodity economies and their foundations in commodity exchange, see, Hudis, P. (ed.) (2014), The Complete Works of Rosa Luxemburg: Volume 1 Economic Writings 1, London: Verso Books.

6 For a discussion of the aligned thoughts concerning commodification in law, see Smith, N. (2009), 'Commodification in law: Ideologies, intractabilities and hyperboles', Continental Philosophy Review, 42 (1), 109-129.

7 Singh Grewal, D. and Purdy, J. (2015), 'Law and neoliberalism', Law and Contemporary Problems, 77, 1-23. Available at: http://scholarship.law.duke.edu/ lcp/vol77/iss4/1 (accessed 12 April 2017). 
theoretical basics of 'what is law' and 'what is law's relevance', at the heart of jurisprudential worrying for generations. ${ }^{8}$

Anticipating the following rejoinders that:

(a) the intention and design of law's connection with property in the neo-liberal era will always be essentially commercial, and that

(b) general good can be dispersed through regulatory regimes which preferentially enrich the few,

the argument to follow is premised on alternative thinking about law's regulatory purpose. ${ }^{9}$

On the way to arguing for law's transformation it is first necessary confront law's validation. In its contemporary form, the lattice of procedures and rules that are legal agency assumes an equitable normative lineage for law, obfuscating the reality that law is but a social fact in a neo-liberal market maze. Law's legitimacy relies on higher-order normative confirmations. Even in its most market-oriented applications law gains purchase not just from enforcement powers, but more convincingly through the networks of trust it facilitates, enabling seamless compliance (see Chapters 6 and 7). For instance, beyond the black letters of private law, its bite is not confined to court room litigation but extends to relationships of trust which the contract embodies and are never the province of legal meddling as a consequence of breach. ${ }^{10}$ In fact,

8 Chekhov's law of relevance applies aptly to the manner in which we employ the notion in the analysis to follow. 'Remove everything that has no relevance to the story. If you say in the first chapter that there is a rifle hanging on the wall, in the second or third chapter it absolutely must go off. If it's not going to be fired, it shouldn't be hanging there.' For a discussion, see Bill, V. (1987), Chekhov: The Silent Voice of Freedom, New York: Philosophical Library. The critical literature on the purpose and relevance of law is vast. One example of the application of natural law to the concept of general good, important in our critique of law's relevance, is Wallin, A.E. (2012), 'John Finnis' natural law theory and a critique of the incommensurable nature of basic goods', Campbell Law Review, 35, 59.

9 This purpose is in part founded on the consequences of critical economic analysis which indicts the future of the capitalist model (see for instance Mason (2015a)). It picks up from this field of critique and problematises the role of law in facilitating rather than frustrating new property arrangements and relationships in markets of the future, particularly for information and knowledge.

10 Macneil, I. (1985), 'Relational contract: What we do and do not know', Wisconsin Law Review, 483-525. 
community sanctions such as banishment from trading clubs, or deregistration from commercial exchanges, may prove to be more effective in policing breaches of contract than the legal enterprise. ${ }^{11}$

Law can provide the form and language for trust bonds to produce market outcomes that could positively impact upon market economies and the societies in which they operate. However, as markets exchange more fictitious commodities, alleged in the analysis to follow, property drifts from the social and becomes a medium for economic relations, priced through market scarcity endorsed by law. Behind these borders of exclusion, market advantage is fostered for the propertied few, undermining law's capacity to act for the general good, compromising law's relevance as a communal resource at a time when its normative prescriptions for fairer power dispersal need to be actioned in order to transcend market change and transform property arrangements (charted in Chapters 3 to 5$)$.

One might question if transformation is superfluous. After all, the age of abundance is not without merit. Our critique, from the perspective of market sustainability ongoing, ${ }^{12}$ confronts the well-worn capitalist contention that economic growth leads to a broadening of individualist wealth creation, no matter how differential. ${ }^{13}$ The 'degrowth' movement argues that the time of abundance has run its course and we need new visions of property and the happiness it can muster. Released from the bondage of free-market monism arising as a consequence of the recent international financial collapse, a new post-capitalist thinking questions both the global primacy of economic governance, and the necessity of the market as the essential social frame. ${ }^{14}$ What is emerging is the sharing economy characterised by networks of communication that facilitate exchange not inextricably tied to market prices, a significant step away

11 Schwartz, A. (2000), 'Contract theory and theories of contract regulation', Yale Law School Faculty Scholarship Series, Paper 313.

12 Our take on sustainability is two-directional. Law has a role in the maintenance of sustainable markets, and in so doing, what we later call new or transformed law becomes largely decommodified and as such sustainable as a community resource - see 'Market economy sustainability', United States Institute for Peace, https://www.usip.org/guiding-principles-stabilization-andreconstruction-the-web-version/sustainable-economy/market-econo (accessed 12 April 2017).

13 Chang, H.J. and Grabel, I. (2014), Reclaiming Development: An Alternative Economic Policy Manual, London: Zen Books.

14 Schiller-Merkens, S. (2013), 'Framing moral markets: The cultural legacy of social movements in an emerging market category', Max Plank Institute for the Study of Societies Discussion Paper 13/8. 
from the commodity-driven neo-liberalism that managed capitalist commodity markets. Forerunners such as Marx and Polanyi, as well as a strong cadre of futurist thinkers generations back, predicted where we are today, witnessing the collapse of the capitalist economic model. If law is to be a vital part of this social and economic transformation we will suggest why and how it must shift its regulatory focus to retain an orderly governance function as the notion of property moves beyond its contemporary materialist recognition.

Law, as a natural extension of the social, retains a transcendental quality that enables it to survive the passage of time, transforming with social conditions, albeit across different forms. Consistent with our use of Polanyi's theory, economic anthropology as a methodology underscores this book's approach to law in change. Indeed, law pre-dated the end of feudalism and the transition into the various stages of capitalist economy. In the circumstances, it makes sense to feature law's regulatory presence in the current and future global regulatory transformation necessitated by profound questions of sustainability and market resilience. Law's complicity in the demise of contemporary economic ordering cannot be excised from the manner in which we have learnt to value property, now a figment of internet transacting.

Paul Mason's Postcapitalism ${ }^{15}$ sets the tone for the contemporary demise of capitalism, not as a theoretical prediction by futurists, but a realist description of what haunts the global cities of today. It is against this backdrop that law's regulatory relevance will be projected. Mason marks our starting point by leaving the important 'whereto' question largely unanswered. Here, we will take up the opportunity to suggest the necessity of a new legal regulatory regime which may avert the anarchy that accompanies histories of radical economic change.

In the feudal age, the role of law was to regulate customs of obligation and dependency. In turn, law, in the various formulations of capitalism, facilitated market arrangements premised on the exclusionist value of property. ${ }^{16}$ Moving forward beyond exchange market societies, law has the choice, we argue, to enable rather than confine access to information and knowledge empowerment.

The shift from an economic model premised on individualist material profit enhancement will be painful for its beneficiaries because, as we will argue, the social has been so heavily skewed through neo-liberalism

\footnotetext{
15 Mason, P. (2015a), Postcapitalism, London: Allen \& Lane.

16 Dagan, H. (2013), Reconstructing American Legal Realism and Rethinking Private Law Theory, Oxford: Oxford University Press.
} 
and its ethos is so intimately interwoven with the contemporary social fabric. Powerful market commodifiers such as legal agency profit as a microcosm of neo-liberal exchange marketing, by enhancing its scarcity as a specialised profession, thus justifying curtailment of admission to constrict supply and access, increasing service pricing and industry remoteness. In this process, the market/social is so intertwined that lawyers who have shared in these limited exchange riches will need to reposition themselves as change agents facilitating emerging forms of human behaviour and social formation. Legal scholars too must be receptive to new understandings of property which will undermine their doctrinal comfort zones.

What should provide some solace to lawyers and those who benefit from legal agency, in uncertain times, are two important possibilities on which we rest our conviction that law can retain its relevance in some new economic order:

(a) The normative framework of law (public and private) is not at odds with the change we envisage. In fact, it is law in form and function which has drifted far from its normative social location, so that law presently operating as a market commodity it is not a comfortable participant in these times of rebalancing.

(b) Major economic transformations risk powerful dislocations from social good even greater than what is currently under challenge, as property changes in value, form and accessibility. Law is a sharpedged regulator, and as the examples we advance later in the book will reveal, it has the capacity to require the forces of transition to act responsibly in terms of its powerful normative principles of justice, fairness and dignity.

Such optimism is tempered by the recognition that, as with Polanyi's commodity fictions, law has been inexorably linked now for centuries to the exploitation of land, labour and money. This market nexus will take more than a bomb to shift. But shift it must, as we are seeing in the revolution of intellectual commons, or legal regulation will be as bereft as is the neutered sanction power of theft criminalisation to control unauthorised internet downloading (see Chapters 2 and 3). Legal fallacies like the position that knowledge is not property, cannot withstand the force of our later analysis in contemporary market thinking.

The regulatory relevance revelation for law and lawyering requires a profound redirection away from neo-liberal facilitation and instead towards the prevailing and inevitable global transition that sees new forms of ownership, diverse conceptualisations of property, new modes of 
lending and even other styles of contracting. Taking from Mason, law and lawyers remain shoulder-to-shoulder with the interests of neo-liberal elites:

... cut off in their dark-limo world - whose project looks as forlorn as that of the millennial sects of the 19th century. The democracy of riot squads, corrupt politicians, magnate-controlled newspapers and the surveillance state looks as phoney and fragile as East Germany did 30 years ago. ${ }^{17}$

At this point there may be readers who reject the dooms-day interpretation of law and the economic order it facilitates. Reading on you will soon realise that the book does the same, but not from the perspective of rehabilitating neo-liberal ordering. Despite law being compromised in many market arrangements, others have argued for law's regulatory relevance grounded in law's normative integrity. We agree, but with the harsh caveat that the challenge is to translate equitable and empowering principle into law's regulatory practice, particularly while capitalist and post-capitalist economic arrangements co-exist. ${ }^{18}$

Continuing the necessary reflection on law's failings which needs to precede arguments for a reinvigorated relevance, these can be reduced to the duality of legal jurisdiction:

(a) Private law, through assisting monopolist market arrangements and restricting property rights has successfully maintained for market economies, the under-utilisation of information, where its inflated commercial valuing is based on scarcity of access.

(b) Public law, through overseeing the demise of the state, its relentless privatisation or its incorporation has legitimated its repressive facilitation of elite interests due to synergistic imperatives to protect elite benefit and denied truly inclusive democratic engagement in the name of liberal democracy and rule of law. ${ }^{19}$

The struggles facing law and legal agency in a quest for relevance are apparent and ominous, whether or not one goes so far as to tie these to the crash and burn of the current global economic model. For instance,

17 Mason P. (2015b), 'The end of capitalism has begun', The Guardian, 17 July 2015, https://www.theguardian.com/books/2015/jul/17/postcapitalismend-of-capitalism-begun (accessed 12 April 2017).

18 Cocksun Samli, A. (2002), In Search of an Equitable, Sustainable Globalization: The Bittersweet Dilemma, Westport, CT: Quorum Books.

19 Horwitz, M. (1977), 'The rule of law: An unqualified human good?', The Yale Law Journal, 86 (3), 561-566. 
no matter how loud the assertions that unauthorised access of information needs the full force of intellectual property penalisation, the relentless perpetuation of the downloading generation fundamentally undermines legal thinking that is narrowly confined to the sanction-based control of impugned property rights violations. Refusing to move from outmoded legal regulatory thinking is as futile as Midas holding back the tide.

By creating millions of networked people, financially exploited but with the whole of human intelligence one thumb-swipe away, info-capitalism has created a new agent of change in history: the educated and connected human being. ${ }^{20}$

Legal regulation needs to switch from hindering social change to promoting it in a just and dignified atmosphere, with which its normative foundations are more than familiar (see Chapter 3). New risk societies are emerging, driven by energy depletion, climate change, health pandemics and ageing populations on the negative ledger, and new social media, massive migration and the explosion of information technology on the positive. ${ }^{21}$ These externalities are placing intense pressure on market economies and altering the dynamics of capitalism in ways which make it unworkable in the long term. ${ }^{22}$ However, we are not advancing a deconstructionist interpretation of legal regulation along with economic transformation. The book warns against unregulated property transformation, fearing that one atmosphere of exploitation and social discrimination will be replaced by another, as human greed shifts into landscapes of deregulated opportunity. ${ }^{23}$

For instance, in today's world of abundant and possibly free information access and the multifarious wealth forms it presents, law is being wedged between:

(a) monopolist multi-nationals, hegemonic international organisations and governments trying to keep things as they are, private, scarce and commercial; and

(b) the inevitable possibilities of abundant information access and exchange.

20 Mason (2015b).

21 Findlay, M. (2013), Contemporary Challenges in Regulating Global Crises, Basingstoke: Palgrave-Macmillan.

22 Mason (2015b).

23 Negri, A. (2010), 'The Law of the Common', Finnish Yearbook of International Law 21, 16-25. 
This situation can only mean that law's positive regulatory potential, without a shift back to much broader community utility, ${ }^{24}$ will be marginalised along with its relevance as a sponsor and protector of passing economic orders (see Chapter 6).

The mission for law in regaining its regulatory relevance, and the occupation of the analysis to follow, is to prefigure its form, function and personnel so as not merely to enable the old to subsist, or even desist with damage control, but to give order to new ways of living. ${ }^{25}$ To achieve this argument in any convincing fashion is no small project. To make the task manageable, we will specifically engage with the alleged failure of globalisation to stimulate new law (see Chapter 6) outside the commercial realm, or to formulate a culturally resilient, tangible or workable notion of global social good. ${ }^{26}$

A fairer understanding of access to original property (see Chapter 6) in a determined global form, it will be advanced, is a necessary normative precondition for repositioning law as a principled regulatory force. So repositioned closer to its own normative frames, new law will enable socially sustainable markets, as well as prevent a disorderly crisis in the transformation of property arrangements and relationships necessary for these markets to reflect strong social ties.

If law's regulatory essence remains inextricably connected to a selfinterested regulatory state mode, and to exclusionist and fictional market economies, we argue that law's relevance will exponentially diminish as the collective conscience of the social radically transforms. By employing three case study interests where the collective conscience regarding access to information, access to legitimate dissent, and access to equitable exchange regimes, is fundamentally contested, the analysis will theorise the forces through law either in preventing or promoting social sustainability. The case studies as the empirical heart of the book (Chapters 3-5) require that law fosters essential social conditions at the centre of law's normative frame but which have been marginalised through the exclusionist applications of legal regulation.

24 Cotterrell, R. (1995), Law's Community: Legal Theory in Sociological Perspective, Oxford: Clarendon Press.

${ }_{25}$ Teubner, G. (2010), 'Societal Constitutionalism and the Politics of the Common', Finnish Yearbook of International Law, 21, 2-15.

26 In current research we will argue that this is not so much a failure of globalisation, which authoritarian, populist resistance argues, but a failure of the neo-liberal economic order that it propagates. 
The book's overarching analytical aim is to reposition law back to a principled regulatory purpose through taking on the function of communal utility and assisting in the essential revaluing of property in order to better reflect strong social ties. In so doing there remains a need to consider how law in principle, relationships and outcomes can better develop as a force for sustainable social bonding in a world where current political economic and social models are under fundamental strain. If the book has a failing it is in not sufficiently specifying how new law will look and act as a bonding mechanism and an agent of responsible change. ${ }^{27}$ That said, we rely on a clear revision in the nexus between law and property that understands property as fundamental social relations, and law as a social fact which must be influential in returning markets for property, back to a world of fair and dignified access rather than a ring-fenced realm of discriminatory and exclusionist rights.

Such a transition will not be achieved without resistance and dissent. In fact, the book identifies in each of its case studies that when law becomes a tool for resisting and denying legitimate dissent, then it fails in its Durkheimian responsibility to temper but not contain the natural reformulations of the collective conscience. As Chapter 4 controversially suggests, pathways for communicating non-violent dissent are qualifications for a healthy global city.

The book concedes, through a consideration of the power of communitarian conversation, the need to tolerate non-violent dissent. Consistent with Luhmann's view, communication in response to violent acts of terror, or indeed even before their emergence, must not retain as any realistic objective, total symmetry or consensus. To do so would smack of oppression, where dissent was originally so sharp. The action which flows from responsible asymmetrical conversations around the underpinnings of terror, we argue will lead to communication avenues and consequent dissent which then will eschew the legitimacy of violence, and thereby build trust around the on-going tolerance of non-destructive asymmetries. The collective conscience is in a constant state of change and is not healthy if mechanically constrained through control devices like violence or even law. That said the conscience is organically maintained in a majoritarian and communitarian interaction that, while employing dissent for transition, returns to a collective entertainment of a

27 This is a focus of our current research examining new law's potential in rehabilitating globalisation through the repositioning of property arrangements in more equitable market power relations. 
new and emerging conscience, reliant on regulation through law for its orderly continuance. The text to follow has several analytical aspirations governing the structure of its argument. In Chapter 1 we introduce the critical context within which regulatory relevance is to be explored: law's dynamic relationship with property in capitalist market economies under threat. Key concepts such as new law and original property are flagged, and conventional considerations concerning property are disentangled. Our theoretical foundations in the form of Polanyi's disembedding, Durkheim's dynamic collective consciences, Proudhon's impossibility of property, and Cotterrell's understandings of law as a communal resource, are set out. The chapter foreshadows forces at work, law principal among these, that suspend commodities and markets away from the social and construct exclusionist power asymmetries denying access to property unless the price can be paid. The chapter concludes with the prospect of radically rethinking law and property wherein law is a facilitator rather than a frustrator of change.

This brings us on to the regulatory failure of criminalising property discussed in Chapter 2. The focus on property and theft in this chapter enables a richer interrogation of property as a capitalist market condition and law as the endorser of its exclusionist rights perspective. Against these discriminatory market imperatives, access to property in alternative congregations of time and space opens up a critique of law as out of touch with more socially located property valuing. Emerging contested consciences about property as community knowledge reveal the gap between new moralities of access, and exclusionist property markets that demand failing criminalisation to ensure scarcity and the position of fictitious commodities. With access rather than rights as the present challenge for legal ordering the chapter bridges into our three case studies, which ground the processes of market disembedding through theorising the suspension of social imagination, and via grassroots resistance, the potential for property to return to the social.

In Chapter 3, the first of our empirical case studies, we interrogate the counter-narrative of unauthorised internet downloading in the context of commodified yoga. We argue that the communitarian collective conscience, in advancing access to information, does more than compress space and time. It challenges exclusionist commodification, and confronts our current understanding of property as profit. Instead, it redefines property as a social rather than an economic relationship. Across internet communities, we trace the virtual reaction against neo-liberal profiteering from even the most traditional of mystical forms, and document how communal resistance, permissible via the virtual, rallies together to resist current definitions of property and to allow for exchanges that are no 
longer shackled by the economic calculus. Another significant theme is how commodified law has created boundaries around access which positions property in such a way that obstructs social relations. Instead of creating a safe haven in which the values of property can be enjoyed beyond price, law ring-fences access so that only a paid-up class of people are permitted entry. Space in which to enjoy access is not drawn against lines of fairness or justice, but rights and rent. The challenge for law is to resume its role as a communal resource, a social fact sensitive to shifts in collective conscience, and to offer an orderly space within which congregations for access can safely convene.

Chapter 4 moves on from information as property, into messages and media for communication. We propose that legitimate pathways for communicating dissent are as much property in the form of social relations, as are now limited by law in terms of rights to ownership and possession. Violence becomes the excepted counter-narrative in these situations both for dissenting communities and the forces pitted against the communication of their message. Despite their assertions over violently contested legitimacy, terrorist acts and violent hegemonic responses fail the responsibility measure even when determined from their individually relative perspectives. The denial of the legitimacy of conversation at the asymmetrical fault lines of dissent and resistance, forestalls any consideration of acceptable dissent levels and forms, as well as their tolerance. Neither terrorism nor violent retributive responses engage the core social motivations for dissent, much less integrating an acceptance of conversation around such themes. Communication at the asymmetrical fault lines within a transforming collective consciousness is an important counter-narrative in the legitimacy crisis fomented through dissent and is the central interest of the communitarian analysis in this chapter.

In Chapter 5 the intentions of the final case study are to explore the impact of free trade on the indigenous market property relations of the South World and to develop our interest in pathways of dissent as the sort of social relations which demonstrate a new way of conceiving and valuing property in contest. Foreign direct investment is identified as a hegemonic device for disempowering fragile market economies to the benefit of a North World-driven global economic agenda. Demonstrated in the relationships of obligation and dependency that such trading arrangements necessitate, corruption develops as a further destructive force which entrenches market power asymmetries and stimulates localist resistance. The chapter is not so much a critique of free trade against protectionism, but rather it represents another encounter where property is removed from the social and exchange markets are disembedded in the 
name of global economic development. Law is exposed through the duplicity of rule of law discourse concealing post-colonial legal imperialism, an essential requirement for the advance of a North World economic empire.

Chapter 6 elaborates the conceptual cornerstones of the analysis. Suspension as an analytical tool is employed in conventional understandings of property and its apparent inseparability from price, power, and profit, thereby showcasing the disembedding movement and corresponding potential for re-embedding of the market. Complementing this is the notion of discontinuity, facilitated by contesting collective consciences in favour of inclusive rather than exclusive access to property.

Chapter 7 concludes by exploring the nature of the transformation anticipated for new law, original property, and the arrangements in which they will engage as regulatory relevance is restored. An attempt to define law as a communal resource, alongside a communitarian demarcation of the social as the new space in which this transition takes place is made. Intellectual property law and legal agency are prime examples illustrating the practicability and value of this endeavour, through the strategic ordering of countermovements.

This book builds on almost a decade of engagement with Polanyi and the insights he affords when struggling to understand how law has overseen the North/South World divide, and the regulatory removal of equality from market possibilities. Findlay's two previous monographs, which are fundamental in the evolution of the thinking to follow, and the book which we now introduce, would not have been possible without Gloria Lee's introduction of Polanyian theorising into the collective thinking. Chapter 3 in its original draft was the research and writing of Gloria Lee Jia En. She contributed materially and intellectually to the other two case studies (Chapters 3 and 4) and her critical comments, analytical insights and acerbic observations enriched all aspects of the book's gestation and culmination. In other circumstances, Lee's contribution would be more prominently recognised. In its present form, this book would not have been possible without her contributions, even beyond the commencement of its writing.

In the realisation of this book as it stands, the project has benefitted from the diligent, dedicated and intuitive research assistance provided by Stephanie Wong Wan Kee.

Writers engaged in the thinking like that which follows are tackling heavy analytical questions, and in doing so demonstrate a distinct commitment for an orderly transition to a more just and humane social. Our task is best represented by Rosa Luxemburg when reflecting on her purpose as an agent of change: 
In my 'soul', a totally new, original form is ripening that ignores all rules and conventions. It breaks them by the power of ideas and strong conviction. I want to affect people like a clap of thunder, to inflame their minds not by speechifying but with the breadth of my vision, the strength of my conviction, and the power of my expression. ${ }^{28}$

28 Luxemburg, R., Hudis, P. and Anderson, K. (2004), The Rosa Luxemburg Reader, New York: Monthly Review Press, p. 382. 
Mark Findlay - 9781785364532 Downloaded from PubFactory at 04/26/2023 09:21:56AM via free access 